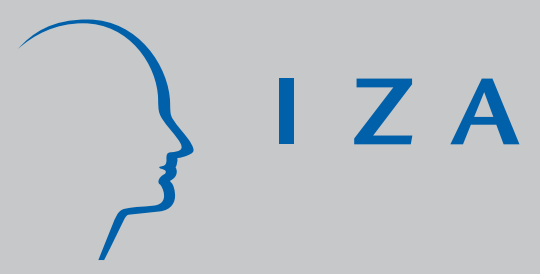

IZA DP No. 4082

Is Bigger Still Better?

The Decline of the Wage Premium at Large Firms

William E. Even

David A. Macpherson

March 2009 


\title{
Is Bigger Still Better? The Decline of the Wage Premium at Large Firms
}

\author{
William E. Even \\ Miami University \\ and IZA \\ David A. Macpherson \\ Florida State University \\ and IZA \\ Discussion Paper No. 4082 \\ March 2009 \\ IZA \\ P.O. Box 7240 \\ 53072 Bonn \\ Germany \\ Phone: +49-228-3894-0 \\ Fax: +49-228-3894-180 \\ E-mail: iza@iza.org
}

\begin{abstract}
Any opinions expressed here are those of the author(s) and not those of IZA. Research published in this series may include views on policy, but the institute itself takes no institutional policy positions.

The Institute for the Study of Labor (IZA) in Bonn is a local and virtual international research center and a place of communication between science, politics and business. IZA is an independent nonprofit organization supported by Deutsche Post Foundation. The center is associated with the University of Bonn and offers a stimulating research environment through its international network, workshops and conferences, data service, project support, research visits and doctoral program. IZA engages in (i) original and internationally competitive research in all fields of labor economics, (ii) development of policy concepts, and (iii) dissemination of research results and concepts to the interested public.
\end{abstract}

IZA Discussion Papers often represent preliminary work and are circulated to encourage discussion. Citation of such a paper should account for its provisional character. A revised version may be available directly from the author. 
IZA Discussion Paper No. 4082

March 2009

\section{ABSTRACT \\ Is Bigger Still Better? \\ The Decline of the Wage Premium at Large Firms}

This study shows that the wage premium paid by large firms fell over the past 20 years and that the decline in the size premium has been most pronounced among the least educated work force. Empirical evidence supports several explanations for the decline in the size premium. First, there has been a convergence in the returns to worker characteristics at large and small firms over time. Second, there has been a convergence in the types of workers employed at small and large firms. Particularly important have been changes in the distribution of workers across industries and the greater rate of decline in unionism at large firms.

JEL Classification: J31, J32, J33

Keywords: firm size, wages, fringe benefits

Corresponding author:

David A. Macpherson

Department of Economics

Florida State University

Tallahassee, FL 32306

USA

E-mail: dmacpherson@fsu.edu 


\section{Introduction.}

The fact that large firms pay higher wages than small firms is a well known result among labor economists. Numerous studies examine the source of the size-premium, and there is empirical support for several different explanations. These include the fact that larger firms employ a more skilled work force, pay efficiency wages to deal with greater monitoring costs, and pay compensating differences for less pleasant working conditions or greater risk that results from the type of human capital that is acquired.

While there has been extensive research attempting to document the cause of the sizepremium, a recent trend has gone unnoticed. Namely, the firm size premium fell substantially over the past 20 years. Moreover, the size-premium fell much more rapidly among less educated workers. This study attempts to uncover an explanation for these trends.

Section 2 provides a brief overview of the existing knowledge on the size-premium. Section 3 discusses our data and provides evidence on trends in the size-premium. Empirical analysis of the trends is provided in section 4.

\section{Background.}

Oi and Idson (1999) provide a wide-ranging summary of the extant research on the sizepremium. Their review points out that the size-premium was first documented nearly 100 years ago among women workers at textile firms. Their summary of empirical studies shows that the largest firms (e.g., firms with 500 or more employees) pay wages that are 30-50 percent higher than the smallest firms (e.g., firms with less than 25 employees). 
Numerous theories for the size-premium have been proposed and no single theory has been sufficient to empirically explain the entire size premium. The more prominent theories for the size premium are based upon monitoring costs, capital/technology effects, working conditions, monopoly power, or union effects.

The monitoring costs explanation for the size-premium was first proposed by Oi (1983). His model argued that monitoring costs would rise with firm size, and this would lead large firms to hire more able workers to conserve on monitoring costs. Because the larger firms hire more able workers, wages will increase with firm size. Also, because of greater monitoring costs, large firms may be more likely to pay efficiency wages or deferred pay to reduce monitoring problems, and utilize higher capital-labor ratios to conserve on the number of workers. Moreover, the greater use of advanced technology by large firms explains part of the sizepremium (Reilly 1995; Dunne and Schmitz 1995; Tan and Batra 1997; Yu et. al 2008).

Yet another explanation for the size-premium is that larger firms must pay a compensating difference for unpleasant work conditions. For example, Brown and Medoff (1989) point to evidence that larger firms have more work rules and less freedom of action, a more impersonal work atmosphere, and are likely to involve greater commuting distances. However, their study finds little support for the hypothesis that inferior working conditions at large firms contribute to the size-premium, but they admit that proper measurement of all relevant working conditions is an arduous task and some studies do find evidence of a compensating difference at large firms. For example, Kostiuk (1990) finds that some of the sizepremium is a compensating difference for shift work that is more common at large firms.

Because larger firms are more likely to have monopoly power in the product markets, some have argued (e.g., Mellow 1982) may engage in rent-sharing with the workers. There is little support found for this hypothesis, however (e.g., Brown and Medoff 1989). 
The union threat hypothesis is that large firms have a greater threat of unionization than small firms and attempt to avoid the union threat by paying higher wages. This would suggest that the size-premium would be larger in the non-union work force. However, Brown and Medoff (1989) find that the size-premium among non-union workers is not higher in occupations or industries where union threats are greatest.

While the brief literature review provided above is by no means an exhaustive list of theories or empirical evidence on the size premium, it provides a general sense of the range of explanations that have been considered. This study does not try to distinguish between the various theories of the size premium. Rather, its objective is to document the trends in the size premium and provide an understanding of why the size premium declined. An understanding of the various theories may assist in interpreting the empirical evidence on this point.

\section{The Data and Trends in the Size Premium.}

To document and examine the size premium, we use data from the March Current Population Surveys (CPS) administered between 1989 and 2008. Because the March CPS asks about earnings in the prior year, the earnings are for 1988 through 2007.

Our measure of the wage is constructed from a person's reported earnings, weeks worked, and hours worked in the prior year. Specifically, for each person we estimate the hourly wage rate as annual earnings divided by the product of weeks worked and usual hours per week. It is important to note that this measure of the wage rate includes any bonuses or overtime that the worker receives. ${ }^{1}$

\footnotetext{
1 Workers with top-coded annual earnings, for the years 1988 to 1994, have been assigned an estimated mean earnings value by assuming that the upper tail of earnings follows a Pareto distribution. Parameters of the Pareto
} 
Our measure of firm size represents the number of workers at the firm, not the establishment. The March CPS data does not provide establishment size. Consequently, if a firm has 5 establishments with 100 workers each, it is classified as a firm with 500 workers. While there is both theory and evidence explaining separate firm and establishment size effects and the explanation of those premia may differ, we are not able to sort out these effects using the March CPS data. ${ }^{2}$

We restrict our sample to private sector wage and salary workers between the ages of 21 and 64. Also, we exclude observations with imputed wages because of the resulting bias that may emerge in the estimation of wage equations. Following the suggestion of Bollinger and Hirsch (2006), we correct for the omission of observations with imputed wages by creating sampling weights that reflect the probability of being included and the sample. The analysis also corrects for the sample-weighting inherent in the CPS data. ${ }^{3}$ In a separate analysis that is not reported here, we find that a failure to correct for the effect of wage imputations leads to an overestimate of the decline in the size premium.

Fringe benefits represent an increasing share of labor costs. Moreover, large firms are more likely to provide benefits like pension and health insurance for their workers. Consequently, adding fringe benefits to the hourly cost of labor can alter both the size and trend in the size premium.

To examine the role of changes in fringe benefit costs on the size-premium, we add the per hour cost of fringe benefits to the wage rate and regenerate estimates of the size-premium

distribution are estimated separately by year and gender. Starting with 1995 earnings, the March CPS assigns the mean value of earnings by demographic group for top-coded workers.

${ }^{2} \mathrm{Oi}$ and Idson (1999) discuss some of the differences between firm and establishment size effects.

${ }^{3}$ The method for weighting is based upon estimation of a probit model of whether a person's wage is imputed as a function of all the control variables used in the wage regressions. This probit model, which is estimated separately by year, is then used to generate a predicted probability of being included in the sample (i.e. the probability that the wage is not imputed). Observations are then weighted by the inverse of this probability times the sampling weights provided by the CPS. 
over time. The two fringe benefits that we focus on are the employer cost of health insurance and pension coverage since the March CPS indicates whether the employee receives these fringe benefits. Unfortunately, the March CPS data does not provide any information on the employer cost of pension or health insurance coverage.

To estimate the hourly cost of health insurance and pensions, we use establishment survey data collected by the Bureau of Labor Statistics to calculate the employer's hourly cost for pension and health insurance separately for small (1-99 employees) and large (100+) establishments for the beginning and ending 5 years of our sample (1988-1992 and 2003-2007). Details on the construction of the fringe benefit data are provided in the data appendix along with a summary of the hourly costs of each fringe benefit by year and education group. For health insurance, we calculate the cost per hour in dollars (conditional on coverage) by firm size; for pensions, we calculate the percentage of wages contributed (conditional on coverage) by firm size. The cost of these benefits (either as a dollar amount or as a percentage of the worker's wage) is added to the hourly wage rate for those who report coverage.

The cost of pension and health insurance benefits rose more rapidly at large than small firms - primarily because large firms are much more likely to offer such benefits. For example, in the 1988-92 period, health insurance coverage rates were $32.4 \%$ and $74.0 \%$ at small and large firms; pension coverage rates were $14.1 \%$ and $61.0 \%$. Consequently, any increase in the cost of these benefits translates into a larger effect on hourly compensation for large employers. In fact, the growth between 1988-92 and 2003-07 in the real hourly cost (in 2007 dollars) at small and large firms was $\$ .43$ and $\$ .89$ for health insurance, and \$.18 and \$.52 for pensions. Consequently, the rising cost of fringe benefits has been greatest at large firms and could have contributed to slower growth in real wages at large firms. 
Trends in the Size Premium.

Figures 1 and 2 provide information on the size premium in log-wages between 1988 and 2007. Figure 1 shows the mean of the log-wage for the four different firm size groupings (1-24, 25-99, 100-499, and 500+), whereas figure 2 illustrates the "size-premium” calculated as the difference in the mean of the log-wage for a given firm size category and that for the smallest firm size group (1-24). ${ }^{4}$ The figures illustrate that, for every year in the sample, wages rise with firm size and that the size-premium decreased over time. For example, for the largest firmsize category (500+ employees), the log-wage premium fell from .46 to .36. The size-premiums for the 25-99 and 100-499 categories are smaller than for the 500+ category and the rate of decline is not as pronounced. In these two groups, the size-premium fell from .20 to .18 and from .30 to .27 over the sample period. This paper focuses on the decline in the size-premium in the largest size category.

Table 1 provides additional information on the size and trend in the size premium over the sample period. The means of the log-hourly wage and log hourly compensation (wages plus pension and health insurance costs) are presented for the beginning and ending five years of the sample (1988-92 and 2003-2007) for the smallest and largest firm sizes. For simplicity, we will refer to these two five year periods by their center points - 1990 and 2005 . The difference between the hourly earnings at large and small firms is the estimated size premium.

For the sample as a whole, the size premium in hourly wages dropped by 9.3 log points (from .424 to .331) between 1990 and 2005. The size premium in hourly compensation (wages plus health insurance and pensions) dropped by 7.0 points (from .495 to .425). Consequently,

\footnotetext{
${ }^{4}$ The CPS actually provides 5 firm size categories, but we combined the 500-999 group with firms that have 1000 or more workers. The trends are not significantly altered by combining these groups and this gives us the advantage of having a larger sample for our analysis.
} 
including fringe benefits increases the size premium but reduces its rate of decline. In fact, approximately one-fourth (2.3/9.3) of the decline in the size premium wages was offset by greater increases in the cost of fringe benefits at large firms.

Earlier work shows that the size premium rises with skill level. For example, Meagher and Wilson (2004) find the size-premium for supervisors is nearly twice that for non-supervisors, and Garen (1985) finds that the size-premium rises with worker education. We find a similar pattern in our data. Table 1 presents the size premium for each of four education groupings: (1) $<12$ years of education; (2) high school graduates; (3) some college, but less than 16 years of education; and (4) a college degree. Regardless of whether the value of fringe benefits are included, the size premium rises with education and the rate of decline in the size premium is most pronounced among the least educated work force. Among high school drop-outs, the size premium in hourly wages dropped by nearly two-thirds from .342 to .127; among college graduates, the premium dropped by nearly one-fifth from .447 to .353 . If fringe benefits are

added to the measure of hourly compensation, the pattern remains the same - the size premium is greater for more educated workers and the drop in the size premium among the least educated workers has been the most pronounced.

\section{Decomposition of the Change in Size Premium.}

Because the evolution of the size-premium over time will depend upon changes in the characteristics of workers and the rewards that workers receive for their human capital at firms of different sizes, it is useful to have a method that allows for a systematic decomposition of changes in the size premium over time. To accomplish this, we use an extension of a Blinder- 
Oaxaca methodology described in Belman and Levine (2004). Their study found a decline in the wage premium between 1979 and 1993 in CPS data and employed a useful decomposition method for empirically estimating the relative importance of various factors in explaining the decline in the size premium.

The first step in the decomposition requires estimation of log-earnings equations by firm size at the beginning and end of the time period in question. In our analysis, we use the beginning and ending five years to examine the change in the size premium over time. We also compare only the largest (500+) and smallest (1-24) employers to examine the size premium and examine log of real hourly compensation because of the aforementioned importance of fringe benefits. That is, we estimate the following hourly compensation equations:

(1) $w_{i t s}=X_{i t s} \beta_{t}^{s}+e_{i t}^{s} \quad ; \mathrm{t}=1,2$ and $\mathrm{s}=\mathrm{S}, \mathrm{L}$

where $\mathrm{w}_{\mathrm{it}}$ is the log of real hourly compensation (wages plus the value of health insurance and pension contributiosn) for person $\mathrm{i}$ in period $\mathrm{t}$ at firm size $\mathrm{s}$; $\mathrm{X}_{\mathrm{it}}$ is a vector of control variables; and $\beta_{t}^{s}$ is the coefficient vector in period t for firm size s. We define $\mathrm{t}=1$ (2) as the early (late) period and s=S (L) as the small (large) firm. Consequently, we estimate four log of hourly compensation equations reflecting two size categories and two time periods.

The change in the size premium can be written as:

(2) $\Delta$ premium $=\left(\bar{w}_{2 L}-\bar{w}_{2 S}\right)-\left(\bar{w}_{1 L}-\bar{w}_{1 S}\right)$ 
where $\bar{w}_{t s}$ is the mean log hourly compensation in period t for firm size s. This change in the premium can be decomposed into several components. To illustrate, define the change in large versus small gap in mean characteristics as:

(3) $\Delta$ Xgap $=\left(\bar{X}_{2 L}-\bar{X}_{2 S}\right)-\left(\bar{X}_{1 L}-\bar{X}_{1 S}\right)$

Define the change in the large-small gap in coefficients as:

(4) $\Delta \beta$ gap $=\left(\beta_{2 L}-\beta_{2 S}\right)-\left(\beta_{1 L}-\beta_{1 S}\right)$

Using the above definitions, the change in the size premium can be decomposed into four parts:

(5) $\Delta$ premium $=\mathrm{A}+\mathrm{B}+\mathrm{C}+\mathrm{D}$

where

(6) $A=\bar{X}_{S} \Delta \beta$ gap

(8) $\mathrm{B}=\left(\bar{X}_{L}-\bar{X}_{S}\right) *\left(\beta_{2 L}-\beta_{1 L}\right)$

(9) $C=\left(\bar{X}_{2 L}-\bar{X}_{1 L}\right)\left(\bar{\beta}_{L}-\bar{\beta}_{S}\right)$

(7) $D=\Delta X g a p \bar{\beta}_{S}$

where $\bar{X}_{L}$ and $\bar{X}_{S}$ represent the average of the early and late values for large and small firm characteristics; and $\bar{\beta}_{L}$ and $\bar{\beta}_{S}$ represent the average of the early and late period coefficients for the large and small firms. 
The first term (A) represents the change in the size premium due to the changing difference in returns in characteristics converging across firm size over time. For example, if the returns to education become more similar at large and small firms over time, the size premium would shrink.

The second term (B) captures any change in the size premium that results if the rewards to characteristics more common at large firm changes over time. For example, if large firms have more educated workers than small firms and the returns to education at large firms rise over time, the size premium would increase.

The third term (C) captures any change in the premium that occurs if the characteristics rewarded more highly at large firms become more common at large firms over time. For example, if large firms pay a higher return to education than small firms and the average level of education at large firms grows over time, the size premium would increase.

The final term (D) represents the change in the size premium due to a convergence of worker characteristics across firm size over time. For example, if the level of education at small and large firms converges over time, the size premium would decrease.

As noted by Jones (1983) and more recently Oaxaca and Ransom (1999), a decomposition of the above parts that involves the gap in coefficients (e.g. parts A, B and C) into the share caused by changes in the return to a specific characteristic is not possible because the results will vary depending upon the reference group chosen. That is, for example, it is not possible to determine how much of the change in the size premium is due to changes in the returns to education across time at small versus large firms. The results of any such decomposition will vary depending upon which education group is chosen as the reference group. The same logic applies to continuous variables where the results will vary depending upon how the variable is scaled. 
The portion of the decomposition that is due to differences in observed characteristics, but not differences in coefficients (D) can be further decomposed to reveal the effect of a specific variable. For example, it is possible to determine how much of the change in the size premium is due to changes in the educational mix of workers at large and small firms. However, the effect of categorical variables like the education dummies must be aggregated across dummy variables for a given characteristic. That is, for example, the amount due to changes in the mix of workers across education groups must be added across all the education dummies.

Otherwise, the results are sensitive to the choice of reference group.

Table 2 presents the means of the control variables by time period and firm size. The last column represents the change in the size-gap for each variable. For example, the "change in gap” value of -0.64 for union membership indicates that the difference between the percentage of workers who are unionized at large versus small firms decreased by .064 between the 1990 and 2005. That is, unionism became relatively less common among employees at large firms over time.

The changing gap in characteristics over time points to several possible explanations for the declining size premium. First, union membership declined at a faster rate among large than small firms. ${ }^{5}$ Since unions are associated with higher wages, this will contribute to a decline in the size premium. Second, since the underrepresentation of women at small firms disappeared over time and because women earn less than men, the size premium would shrink.

The average worker's education increased at both small and large firms over time, but the increase has been more pronounced at large firms. The more rapid increase in education at large firms should lead to a larger size premium over time and must have been offset by other forces.

\footnotetext{
${ }^{5}$ Union membership is matched to the March CPS from the March to June outgoing rotation group files. While the earnings measure is for earnings in the prior year, the union status variable corresponds to the worker's union status in the reference week in the relevant outgoing rotation group file. Estimates of the size premium change only slightly if the sample is expanded to include observations with missing data on union membership.
} 
Finally, full-time work (measured either by hours per week or weeks per year) has become relatively less common at large firms over time. Given that full-time work generally pays more, this would lead to a decrease in the size premium. ${ }^{6}$ Finally, there have been significant changes in the distribution of employment across industries, but measuring the effect of the changing industrial changes requires knowledge of how the size premium varies across industries.

Estimates of the log of hourly compensation equations are presented in table $3 . \quad$ To emphasize size-difference in returns, we present the coefficients on each of the characteristics along with interaction terms between a large firm size dummy and each of the characteristic. The coefficients on the interaction terms reveal how the returns to that characteristic differ for large and small firms.

The log hourly compensation regressions include controls for age, education, union membership, industry, occupation, full-time ( $\geq 35$ hours per week) and full-year ( $\geq 50$ weeks per year) status, sex, race. The results are presented in table 3.

The coefficients on the interaction terms between characteristics and the dummy for large firm size suggest several important determinants of the size premium. First, in both 1990 and 2005, the size premium rises significantly with age. This has been noted in other studies and may reflect a greater proclivity to invest in specific training at large firms or greater reliance on deferred pay to reduce monitoring or turnover costs. ${ }^{7}$ Second, the size premium is lower among unionized workers, though the effect is statistically insignificant in 2005. This is consistent with evidence that unions equalize wages and therefore reduce the wage gap between workers at small and large firms. ${ }^{8}$ Third, the returns to education are greater at large than small firms and the higher return at large firms has grown over time. Finally, the size premium varies substantially

\footnotetext{
${ }^{6}$ For evidence that part-time workers earn less, see Hirsch (2005).

${ }^{7}$ Oi and Idson (1999) discuss several studies that find steeper age-earnings profiles at large firms, but note a couple of exceptions to these findings.

${ }^{8}$ See Freeman and Medoff (1984).
} 
across industry. For example, in 1990, the size premium was 35 log-points higher in transportation than in the non-hospital medical industry. Consequently, a shift of workers across industries has the potential to substantially alter the size premium.

The decomposition of the change in the firm size premium in hourly compensation is presented in table 4. The decomposition is performed for all workers, and then for each of the four education groups. For all workers, the size premium in hourly compensation decreased by 7.0 log points between 1990 and 2005. Of this decline, 3.0 log points are due to the returns to characteristics converging across time at small and large firms. As noted earlier, we cannot provide a further decomposition of this overall effect of converging returns since the results vary depending upon the reference group chosen. The obvious question is why the returns to worker characteristics converged over time. Possible explanations can be drawn from the theoretical explanations for the size premium that are not controlled for in our regression and potentially correlated with the included regressors. For example, if large firms are more likely to pay efficiency wages than small firms because of greater monitoring costs, any reduction in monitoring costs that is greater at large firms will result in a convergence in returns to characteristics. Alternatively, suppose large firms use more advanced technology (or more capital) than small firms and extract greater effort to improve the return on the expensive technology, if the size-gap in technology is reduced, the return to characteristics would converge at small and large firms. While there are numerous potential explanations for the size-gap in returns to characteristics, sorting out these effects requires more data than is available in the CPS.

The other major source of the decline in the size premium is that the characteristics of the workers at small and large firms converged over time. This led to a decline of 4.1 log points in the size premium between the early and late period. The bottom of table 4 provides a further 
breakdown of this part of the decomposition. It reveals that $1.5 \log$ points of the decline in the size premium occurred because union membership fell faster at large than small firms. Another 0.7 log points of the decline occurred because the share of employees that are women has been rising faster at large than small firms. This contributes to a decline in the size premium because women have lower earnings than men, even after controlling for other observed characteristics. The distribution of workers across industries changed substantially over time, and the employment shifts differed for large and small firms. Some of the more notable changes included declines in durable and non-durable manufacturing that were more pronounced among large firms and a more rapid increase in the share of workers in retail trade (see table 2). Since the size premium in durable and nondurable manufacturing is larger than that in retail trade (see table 3), this redistribution of employment will contribute to a decline in the size premium. Overall, the redistribution of workers across industries is estimated to have caused a decline of 2.0 log-points in the size premium.

The overall conclusion that we draw from the decomposition for all workers combined is that 4.1 points of the 7.0 log point decline in the size premium of hourly compensation is accounted for by a convergence of worker characteristics at large and small firms. The most important factors contributing to a decline in the size premium were a more rapid decline in unionism at large firms, and a shift of employment away from manufacturing and toward retail at large firms.

Decomposition by Education Group.

The rate of decline in the size premium is much greater among less educated workers. To explore why this has occurred, decompositions of the change in the size premium for four 
separate education groups based on years of education $(<12,12,13-15,16+)$ are presented in the last four columns of table 4. The results, presented in the last four columns of table 3, imply that the convergence in the returns to characteristics among small and large firms had the greatest effect among those with less than a high school degree. Holding observable characteristics constant, small and large firms have become much more similar in terms of how they reward all their workers, but especially the least skilled group. Existing theories of the size premium provide some interesting hypotheses about why this may have occurred. For example, based upon the monitoring theory of the size-premium, if technological advances have improved the ability of large firms to monitor workers - particularly less skilled workers - the size premium would shrink most for the least educated workers.

Another important conclusion to be drawn from the analysis by education group is that worker characteristics are converging in all four education groups - but the effects of convergence are greatest among the least educated. For example, convergence of characteristics explains 12.4 and 4.1 log-points of the decline in the size premium for the least and most educated groups respectively. Analysis of the decomposition by characteristic reveals that the more rapid rate of decline in unionism at the large firms and the changing distribution of employment across industries contributed to a substantial decline in the premium among less educated workers. The magnitude of these effects are smaller or non-existent among the more educated workers.

\section{Summary and Conclusions.}

Our study documents a significant decline in the wage premium paid by large employers over the past 15 years. In the aggregate, the gap in the log-wage paid by large (500+ 
employees) and small (<25 employees) fell from .46 to .36 . Also, while the size premium is greater among the most educated workers, the rate of decline in the size premium has been greatest among the least educated workers. Among workers with less than 12 years of education, the size premium fell by nearly two-thirds over the past 15 years.

Our analysis suggests that approximately one-quarter of the shrinkage in the size premium in wages was offset by more rapid increases in fringe benefit costs at large firms. A decomposition of the change in the size premium in hourly compensation reveals that nearly 60 percent of the decline in the size premium was caused by a convergence of characteristics (particularly union membership and industry) across firm size.

The sharp decline in the size premium for less educated workers is partly the result of a reallocation of workers toward industries where the size premium is lower (e.g. from manufacturing to retail) and a more pronounced decline in union membership. However, it is important to note that there has been a pronounced convergence of the return to characteristics at small and large firms - particularly for the least educated work force. The fact that the returns to characteristics are rapidly converging at small and large firms presents several possible avenues for future research. For example, is the convergence in pay structure at large and small firms because they are adopting more similar technology? Is it because large and small firms have become more similar in terms of the unobservable skills of workers that they attract? Have working conditions, or other non-pecuniary aspects of the jobs at large and small firms become more similar? Or could increased competition from globalization have reduced the ability of large firms to share rents with their workers? Moreover, it is interesting to consider why the returns to characteristics converged most for the least educated workers. 


\section{References}

Belman, Dale and Levine, David I. “Size, Skill, and Sorting.” Labour 18 (December 2004): 515561.

Bollinger, Christopher R., and Hirsch, Barry T. "Match Bias from Earnings Imputation in the Current Population Survey: The Case of Imperfect Matching.” Journal of Labor Economics 24 (July 2006): 483-519.

Brown, Charles and Medoff, James, “The Employer-Size Wage Effect.” Journal of Political Economy 97 (October 1989): 1027-1059.

Dunne, Timothy and Schmitz, James A. "Wages, Employment Structure and Employer SizeWage Premia: Their Relationship to Advanced-Technology Usage at US Manufacturing Establishments.” Economica 62 (February 1995): 89-107.

Freeman, Richard B. and Medoff, James L. What Do Unions Do? (New York: Basic Books, 1984).

Garen, John. "Worker Heterogeneity, Job Screening, and Firm Size." Journal of Political Economy 93 (August 1985): 715-739

Barry T. Hirsch, "Why Do Part-Time Workers Earn Less? The Role of Worker and Job Skills," Industrial and Labor Relations Review 58 (July 2005): 525-51.

Jones, F. L. "On Decomposing the Wage Gap: A Critical Comment on Blinder's Method," Journal of Human Resources 18 (Winter1983): 126-130.

Kostiuk, Peter. “Compensating Differentials for Shift Work,” Journal of Political Economy 98 (October 1990): 1054-1075.

Lallemand, Thierry; Plasman, Robert; and Rycx, Francois. "Why do Large Firms Pay Higher Wages? Evidence From Matched Worker-Firm Data.” International Journal of Manpower 26 (Issue 7/8 2005): 705-723.

Meagher, Kieron J. and Wilson, Hugh. "Different Firm Size Effects on Wages for Supervisors and Workers.” Economics Letters (August 2004): 225-230.

Mellow, Wesley, "Employer Size and Wages," Review of Economics and Statistics 64 (August 1982): 495-501.

Oaxaca, Ronald L. and Ransom, Michael R. "Identification in Detailed Wage Decompositions." Review of Economics and Statistics 81 (February 1999): 154-157. 
Oi, Walter Y "Heterogeneous Firms and the Organization of Production", Economic Inquiry 21 (1983): 147-171

and Idson, Todd L. "Firm Size and Wages." In Handbook of Labor Economics, Volume 3. editors Orley Ashenfelter and David Card (Amsterdam: North-Holland, 1999), 2165-2214.

Reilly, Kevin T. "Human Capital and Information: The Employer Size-Wage Effect.” Journal of Human Resources 30 (Winter 1995): 1-18.

Tan, Hong and Batra, Geeta. “Technology and Firm Size-Wage Differentials in Colombia, Mexico, and Taiwan.” The World Bank Economic Review 11 (January 1997): 59-83.

Yu, Li; Hurley, Terry M.; Kliebenstein, James B; and Orazem, Peter F. “Firm Size, Technical Change and Wages in the Pork Sector, 1990 -2005.” Iowa State University Working Paper Number 08013, August 2008. 


\section{Data Appendix.}

\section{Calculation of Hourly Value of Fringe Benefits}

The Current Population Survey indicates whether workers have health insurance or pension coverage, but does not provide any information on the hourly cost of those benefits. The following process was used to estimate the hourly value of fringe benefits. First, the employer cost of health insurance and pensions was obtained by employer size from the Employer Expenditures for Employee Compensation (http://www.bls.gov/ncs/ect/). This data includes assigns a cost of 0 for those not covered by health insurance or pensions. This data is provided annually by establishment size for private-sector workers from 1990 forward (ftp://ftp.bls.gov/pub/special.requests/ocwc/ect/ecechist.txt and ftp://ftp.bls.gov/pub/special.requests/ocwc/ect/ececqrt.txt). The data for establishments with 1 to 99 employees was merged to workers in CPS employed at firms with 1 to 25 workers and the data for establishments with 100 and more employees was used for firms with 500 or more workers.

Second, the reported hourly benefit costs obtained from the prior step were divided by the coverage rate for health insurance and pensions to obtain the hourly employer cost for those covered. The coverage rates for pensions and health insurance at establishments with 1 to 99 employees was obtained from Employee Benefits in Small Private Industry Establishments (1992, 1994, 1996) (http://www.bls.gov/schedule/archives/all_nr.htm\#EBS) and Employee Benefits Survey (1999, 2000, 2003, 2004, 2005, 2006, 2008) (http://www.bls.gov/ncs/ebs/) . The coverage rates for pensions and health insurance at establishments with 100 or employees was obtained from Employee Benefits in Medium and Large Establishments (1991, 1993, 1995, 1997) (http://www.bls.gov/schedule/archives/all_nr.htm\#EBS3D) and Employee Benefits Survey (1999, 
2000, 2003, 2004, 2005, 2006, 2008). Interpolation was used for years for which coverage rates were not available.

Third, the hourly costs for years 1988 to 1990 was obtained by scaling the 1991 hourly cost figures by the rate of increase in employer cost of health insurance and pensions in Employer Expenditures for Employee Compensation.

Table A-1 summarizes fringe benefit coverage and costs (in 2007 dollars) by firm size for the early (1988-92) and late (2003-07) time periods. Both health insurance and pension coverage are more common at large than small firms, though the size-gap in coverage diminished slightly over time. The employer contributions for fringe benefits are greater at large than small firms because coverage rates are higher and the cost per hour given coverage is higher. Even though the percentage of workers covered by health insurance and pensions fell at large firms, the average hourly cost (including those without coverage) rose at large firms relative to small firms over time.

Table A-1 Means of Employer Fringe Benefit Costs by Firm Size and Time Period

\begin{tabular}{|c|c|c|c|c|c|c|}
\hline \multicolumn{3}{|c|}{1988 to 1992} & \multicolumn{3}{|c|}{2003 to 2007} & \multirow[b]{2}{*}{$\begin{array}{l}\text { Change } \\
\text { in Gap }\end{array}$} \\
\hline $\begin{array}{c}1 \text { to } 24 \\
\text { Workers }\end{array}$ & $\begin{array}{c}500+ \\
\text { Workers }\end{array}$ & Gap & $\begin{array}{c}1 \text { to } 24 \\
\text { Workers }\end{array}$ & $\begin{array}{c}500+ \\
\text { Workers }\end{array}$ & Gap & \\
\hline
\end{tabular}

Health Insurance Coverage Health insurance hourly cost given coverage Health Insurance Hourly Cost Pension Coverage Pension Hourly Cost given coverage Pension Hourly Cost

$\begin{array}{lllllll}32.4 \% & 74.0 \% & 41.6 \% & 33.8 \% & 70.0 \% & 36.2 \% & -5.4 \% \\ \$ 1.76 & \$ 2.20 & \$ 0.45 & \$ 2.96 & \$ 3.59 & \$ 0.63 & \$ 0.19 \\ \$ 0.57 & \$ 1.63 & \$ 1.06 & \$ 1.00 & \$ 2.52 & \$ 1.51 & \$ 0.45 \\ 14.1 \% & 61.0 \% & 46.9 \% & 20.4 \% & 59.6 \% & 39.2 \% & -7.8 \% \\ & & & & & & \\ \$ 1.84 & \$ 1.66 & -\$ 0.18 & \$ 2.14 & \$ 2.74 & \$ 0.60 & \$ 0.78 \\ \$ 0.26 & \$ 1.01 & \$ 0.76 & \$ 0.44 & \$ 1.63 & \$ 1.20 & \$ 0.44\end{array}$


Figure 1.

Real Wages by Firm Size
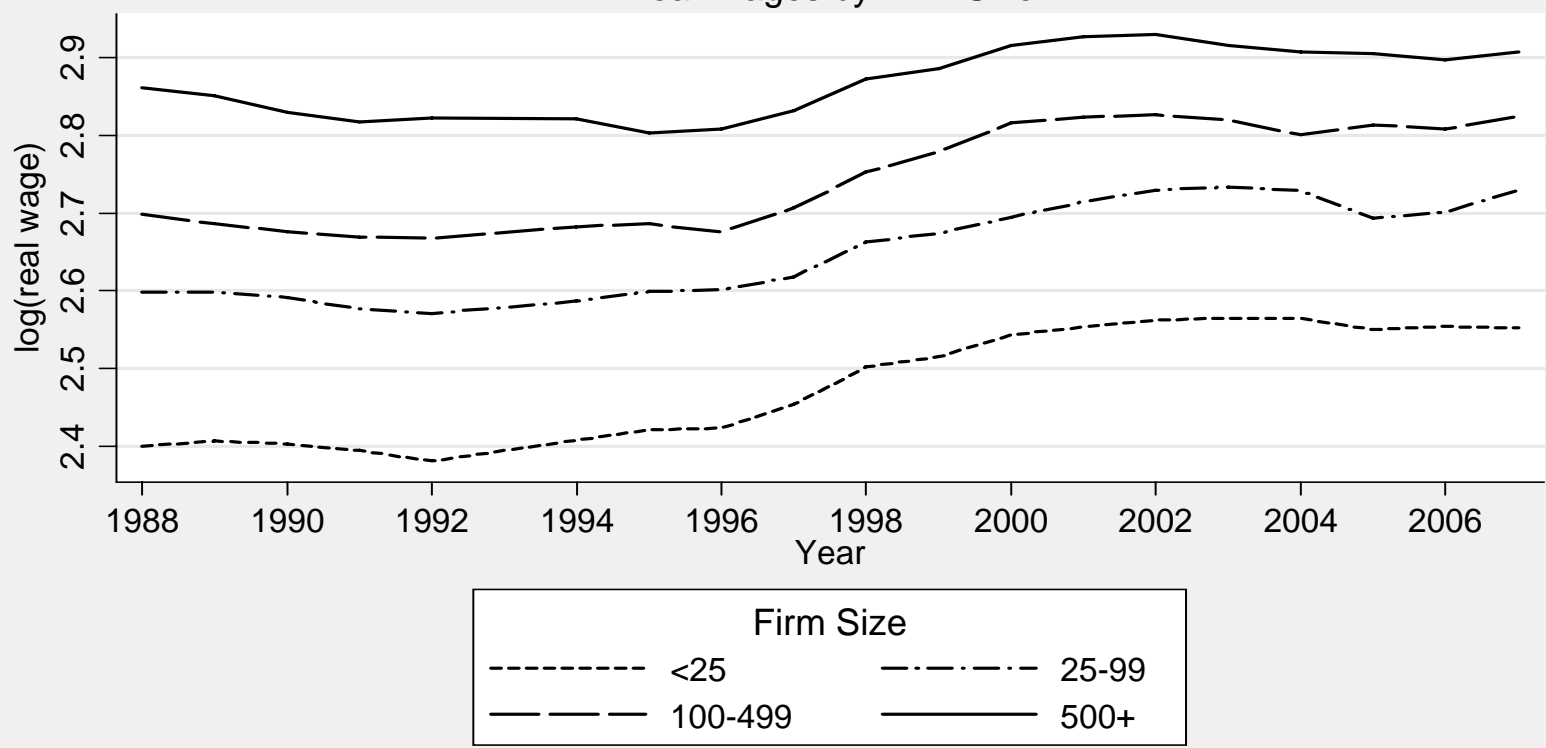

Sample includes private - sector workers who are aged 21 to 64 with non - allocated earnings

Figure 2.

Wage Premium Relative to Smallest Firms
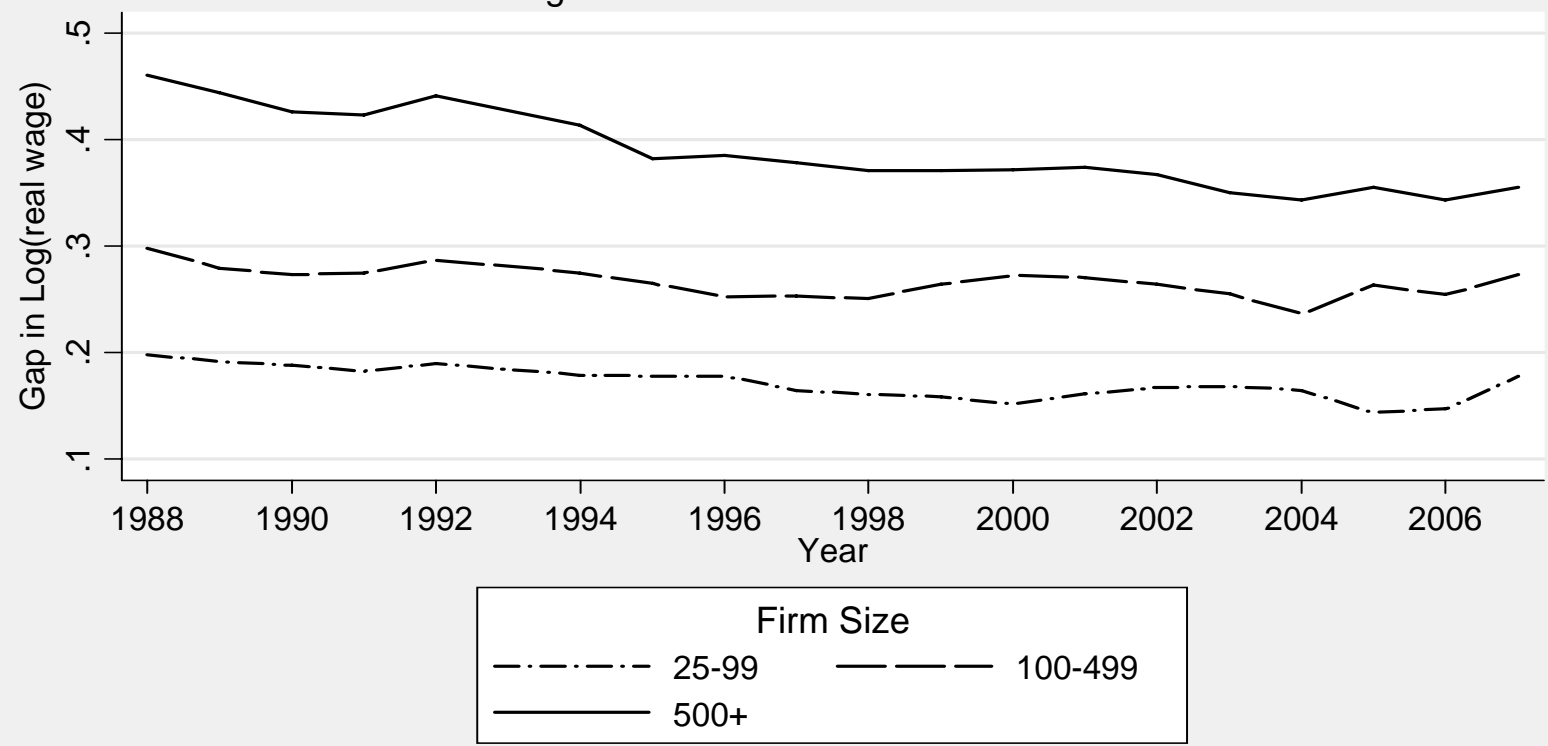

Sample includes private - sector workers who are aged 21 to 64 with non - allocated earnings 
Table 1

Means of Log Wages and Compensation by Firm Size and Time Period ${ }^{\text {a }}$

All Workers

Log Real Hourly Wage

Log Real Hourly Compensation

High School Dropouts

Log Real Hourly Wage

Log Real Hourly Compensation

High School Graduates

Log Real Hourly Wage

Log Real Hourly Compensation

Some College

Log Real Hourly Wage

Log Real Hourly Compensation

College Graduates

Log Real Hourly Wage

Log Real Hourly Compensation

Sample Size

\begin{tabular}{|c|c|c|c|c|c|c|}
\hline \multicolumn{3}{|c|}{1988 to 1992} & \multicolumn{3}{|c|}{2003 to 2007} & \\
\hline $\begin{array}{l}1 \text { to } 24 \\
\text { Workers }\end{array}$ & $\begin{array}{c}500+ \\
\text { Workers }\end{array}$ & Gap & $\begin{array}{l}1 \text { to } 24 \\
\text { Workers }\end{array}$ & $\begin{array}{c}500+ \\
\text { Workers }\end{array}$ & Gap & $\begin{array}{l}\text { Change } \\
\text { in Gap }\end{array}$ \\
\hline
\end{tabular}

$\begin{array}{lllllll}2.457 & 2.881 & 0.424 & 2.602 & 2.933 & 0.331 & -0.093 \\ 2.516 & 3.011 & 0.495 & 2.686 & 3.111 & 0.425 & -0.070\end{array}$

$\begin{array}{lllllll}2.199 & 2.541 & 0.342 & 2.261 & 2.388 & 0.127 & -0.215\end{array}$

$\begin{array}{lllllll}2.239 & 2.678 & 0.439 & 2.312 & 2.548 & 0.235 & -0.203\end{array}$

$\begin{array}{lllllll}2.389 & 2.745 & 0.356 & 2.496 & 2.706 & 0.209 & -0.147\end{array}$

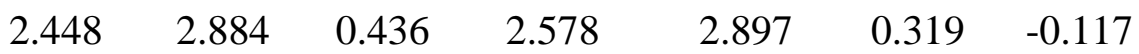

$\begin{array}{lllllll}2.507 & 2.869 & 0.362 & 2.606 & 2.846 & 0.240 & -0.122\end{array}$

$\begin{array}{lllllll}2.568 & 2.994 & 0.427 & 2.695 & 3.025 & 0.330 & -0.097\end{array}$

$\begin{array}{lllllll}2.768 & 3.214 & 0.447 & 2.943 & 3.296 & 0.353 & -0.093\end{array}$

$\begin{array}{lllllll}2.839 & 3.333 & 0.494 & 3.042 & 3.465 & 0.422 & -0.072\end{array}$

$40,755 \quad 76,432 \quad 38,887 \quad 69,196$

${ }^{a}$ Note: Log hourly compensation includes the dollar value of health insurance and pension benefits. 
Table 2

Mean Characteristics by Size and Time Period

Female

Age

Union Member

Years of Schooling

Industry:

Construction

Durable Manufacturing

Non-Durable Manufact.

Wholesale Trade

Retail Trade

Personal Services

Entertainment

Non-Hospital Medical

Other Industries

Occupation:

Managers

Professionals

Technicians

Sales

Administrative Support

Private Household

Precision Production

Operators

Other Occupations

Full-time (35 + hours/week)

Full-year (50+ weeks/year)

Sample Size

\begin{tabular}{ccc|cccc|c}
\hline \multicolumn{3}{c|}{1988 to 1992} & \multicolumn{3}{c|}{2003 to 2007} & \\
\hline 1 to 24 & $500+$ & & 1 to 24 & $500+$ & & $\begin{array}{c}\text { Change } \\
\text { in Gap }\end{array}$ \\
Workers & Workers & Gap & Workers & Workers & Gap & Wo. \\
\hline 0.505 & 0.470 & -0.035 & 0.482 & 0.486 & 0.004 & 0.039 \\
36.018 & 36.915 & 0.897 & 38.704 & 39.288 & 0.584 & -0.314 \\
0.051 & 0.198 & 0.147 & 0.040 & 0.123 & 0.083 & -0.064 \\
12.698 & 13.349 & 0.651 & 13.089 & 13.905 & 0.817 & 0.166
\end{tabular}

$\begin{array}{lllllcc}0.108 & 0.017 & -0.091 & 0.132 & 0.023 & -0.109 & -0.018 \\ 0.057 & 0.205 & 0.148 & 0.054 & 0.125 & 0.071 & -0.077 \\ 0.042 & 0.136 & 0.094 & 0.03 & 0.083 & 0.053 & -0.041 \\ 0.063 & 0.038 & -0.025 & 0.042 & 0.037 & -0.005 & 0.020 \\ 0.198 & 0.168 & -0.03 & 0.178 & 0.208 & 0.030 & 0.060 \\ 0.064 & 0.024 & -0.04 & 0.055 & 0.023 & -0.032 & 0.008 \\ 0.014 & 0.005 & -0.009 & 0.016 & 0.016 & 0.000 & 0.009 \\ 0.080 & 0.016 & -0.064 & 0.084 & 0.042 & -0.042 & 0.022 \\ 0.374 & 0.391 & 0.017 & 0.409 & 0.443 & 0.034 & 0.017\end{array}$

0.110

0.133

0.023

0.129

0.038

0.126

0.169

0.043

0.020

0.091

0.055

0.021

0.116

0.041

0.119

$-0.001$

0.106

0.179

0.017

0.14

0.000

$-0.021$

0.007

0.120

$-0.036$

0.156

0.110

0.060

$-0.102$

0.124

0.137

0.174

0.058

0.019

0.047

0.005

$-0.016$

0.138

0.031

0.032

0.145

0.006

$-0.011$

0.002

$-0.005$

0.016

0.090

$-0.066$

$-0.030$

0.257

0.155

0.669

0.806

$40,755 \quad 76,432$
0.041

0.267

0.796

0.768

0.062

0.020

0.173

$-0.094$

$-0.040$

0.884

$\begin{array}{ll}0.088 & -0.037\end{array}$

0.837

0.069

$38,887 \quad 69,196$ 
Table 3

Regressions for Hourly Compensation Decompositions ${ }^{\text {a }}$

Variable

Female

Education (elementary school omitted):

High School Dropout

High School Graduate

Some College

College Graduate

Graduate School

Union Member

Age (age 18 to 24 omitted):

25 to 34

35 to 44

45 to 54

55 to 64

Industry (agriculture omitted)

Mining

Construction

Durable Manufacturing

Nondurable Manufacturing

Transportation

Communications

\begin{tabular}{|c|c|c|c|}
\hline \multicolumn{2}{|c|}{1988 to 1992} & \multicolumn{2}{|c|}{2003 to 2007} \\
\hline Characteristic & $\begin{array}{c}\text { Characteristic } \\
* \text { Big }\end{array}$ & Characteristic & $\begin{array}{c}\text { Characteristic } \\
* \text { Big }\end{array}$ \\
\hline-0.176 & -0.0555 & -0.177 & 0.0153 \\
\hline$(-17.0)$ & $(-4.88)$ & $(-17.1)$ & (1.30) \\
\hline
\end{tabular}

$\begin{array}{lccc}0.123 & -0.0343 & 0.116 & 0.0376 \\ (6.61) & (-1.42) & (4.70) & (1.11) \\ 0.218 & 0.00361 & 0.262 & 0.0638 \\ (13.4) & (0.17) & (11.7) & (2.13) \\ 0.310 & -0.00636 & 0.357 & 0.0694 \\ (18.3) & (-0.29) & (15.6) & (2.27) \\ 0.441 & 0.0186 & 0.516 & 0.122 \\ (22.5) & (0.76) & (21.1) & (3.79) \\ 0.577 & 0.00448 & 0.747 & 0.0883 \\ (22.4) & (0.15) & (24.4) & (2.32) \\ 0.206 & -0.0458 & 0.170 & -0.0147 \\ (13.2) & (-2.79) & (8.80) & (-0.71)\end{array}$

$\begin{array}{llll}0.189 & 0.0250 & 0.180 & 0.0479\end{array}$

(17.6)

(1.89)

(13.4)

(2.85)

0.266

0.0913

0.288

0.124

(23.8)

(6.70)

(22.0)

(7.52)

0.284

0.123

0.312

0.146

(23.0)

(8.25)

(22.3)

(8.48)

0.251

0.142

0.312

0.125

(17.0)

(8.06)

(20.0)

(6.56)

0.465

$-0.0319$

0.325

0.0753

(7.09)

$(-0.35)$

(5.11)

(0.98)

0.276

0.0429

0.155

0.0760

(8.97)

(0.61)

(5.74)

(1.58)

0.246

0.0342

0.109

0.102

(7.84)

(0.50)

(3.86)

(2.17)

0.140

0.0887

0.00185

0.164

(4.23)

(1.27)

(0.055)

(3.24)

0.157

0.164

0.0259

0.120

(4.69)

(2.33)

(0.80)

(2.38)

0.127

0.217

$-0.00113$

0.186 
Table 3

Regressions for Hourly Compensation Decompositions ${ }^{\text {a }}$

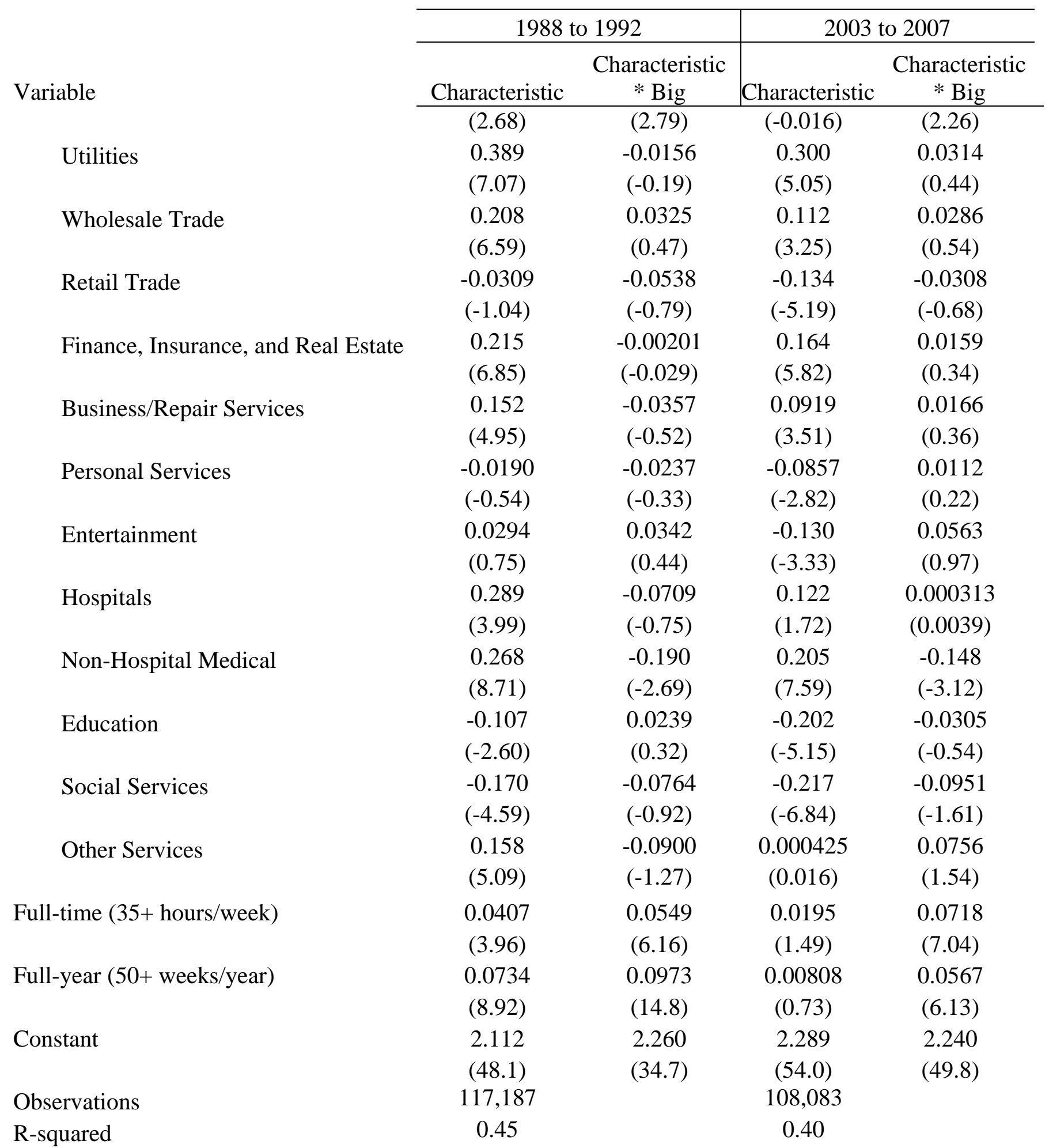

${ }^{a}$ The dependent variable is log real hourly compensation, which equals the real hourly wage plus the dollar value of health insurance and pension benefits. The regressions also include controls for central city status (2), state (50), and race (2). 
Table 4

Decomposition of the Change in Firm Size Premium for Log Real Hourly Compensation ${ }^{\mathrm{a}}$

\begin{tabular}{|c|c|c|c|c|c|}
\hline Change in size premium & $\begin{array}{c}\text { All } \\
-.070\end{array}$ & $\begin{array}{l}\text { Dropout } \\
-.203\end{array}$ & $\begin{array}{l}\text { HS } \\
\text { Grad } \\
-.117\end{array}$ & $\begin{array}{l}\text { Some } \\
\text { College } \\
-.097\end{array}$ & $\begin{array}{l}\text { College } \\
-.072\end{array}$ \\
\hline \multicolumn{6}{|l|}{ Portion of change due to: } \\
\hline $\begin{array}{l}\text { A. Convergence of returns at large and } \\
\text { small firms }\end{array}$ & -.030 & -.132 & -.034 & -.020 & -.022 \\
\hline $\begin{array}{l}\text { B. Changing returns for } \\
\text { characteristics particularly common at } \\
\text { large firms }\end{array}$ & .001 & .079 & -.002 & -.028 & -.016 \\
\hline $\begin{array}{l}\text { C. Differential reward to } \\
\text { characteristics more common at large } \\
\text { firms changes over time }\end{array}$ & -.001 & -.026 & -.005 & -.001 & .008 \\
\hline $\begin{array}{l}\text { D. Convergence of characteristics of } \\
\text { workers at large and small firms. }\end{array}$ & -.041 & -.124 & -.077 & -.049 & -.041 \\
\hline \multicolumn{6}{|l|}{ Decomposition of (D) } \\
\hline Female & -.007 & -.008 & -.008 & -.006 & -.009 \\
\hline Education & .011 & .001 & .000 & .000 & .002 \\
\hline Union & -.015 & -.045 & -.024 & -.010 & .000 \\
\hline Age & -.005 & -.009 & -.004 & -.009 & .003 \\
\hline Race & .000 & -.001 & .001 & .002 & .001 \\
\hline Central City & -.003 & -.006 & -.005 & .000 & -.006 \\
\hline Industry & -.020 & -.041 & -.029 & -.015 & -.021 \\
\hline Occupation & .006 & -.009 & .002 & -.004 & .001 \\
\hline Full-time/Full-year & -.007 & -.004 & -.007 & -.007 & -.008 \\
\hline State & -.001 & -.001 & .000 & .000 & -.004 \\
\hline
\end{tabular}

a The firm size premium is the log-hourly compensation premium for firms with $500+$ workers relative to those with 1-25 workers. The change in size-premium is measured between the 1988-92 and the 2003-2007 periods. 